\title{
Design and Analysis of Heavy Duty Truck Brake Drum and Shoe
}

\author{
Waza Muluken Tadesse \\ School of Automobile \& Transportation Engineering \\ Tianjin University of Technology \& Education No.1310 \\ Dagu Nan Lu Hexi District \\ Tianjin, China
}

\author{
Zhang Lei \\ School of Automobile \& Transportation Engineering \\ Tianjin University of Technology \& Education No.1310 \\ Dagu Nan Lu Hexi District \\ Tianjin, China
}

\begin{abstract}
The effect of materials on the brake performance of heavy duty truck is studied using analysis software. The drum and shoe model of heavy duty truck were designed by CATIA software and by using various brake materials as a design variables the structural and thermal analysis of the imported model was done on ANSYS software. Finite element method was utilized and the meshing element size and shape were defined to find solution for stress, strain, deformation, temperature and heat flux of the brake drum and shoe. The result of analysis showed that by assigning different materials better brake performance can be achieved. Aluminum metal matrix composite F3D205-T5, one of the four assigned brake materials has better characteristics of thermal dissipation and light weight than cast iron and carbon steel and it has moderate deformation characteristics similar to cast iron. Because of its observed better characteristics Aluminum metal matrix composite F3D205-T5 can be treated as an alternative brake material for brake drum and shoe.
\end{abstract}

Keywords: Brake Drum, Brake Shoe, Structural Analysis, Thermal Analysis

\section{INTRODUCTION}

Brake is a safety device installed in a motor vehicle to control the movement of the vehicle; it decelerates the speed of the vehicle or stops the vehicle [1]. Based on the type of construction motor vehicle brake can be classified into disc brake and drum brake. The drum brake is consisted of brake drum, brake shoe (pad) and wheel cylinders or brake chambers (for pneumatic brake). The brake force exerted by the driver on the brake pedal is transformed into brake pressure of brake shoe or pad and this pressure is distributed throughout the circumference of the brake drum to decelerate the velocity of the vehicle. The friction between the expanded brake shoe and the rotating brake drum generates heat and the generated heat is absorbed by brake fluid, mechanical parts and surrounding atmosphere. To prepare the brake drum for continuous brake application the absorbed heat might be removed from the brake system rapidly.

The performance of brake to control the motion of a vehicle is depends up on many factors. The mechanics of the braking process suggest that there are at least five distinct facets of braking performance deserving of considerations for passengers car and commercial vehicles. These facets or measures of braking performance may be referred to as effectiveness, efficiency, response time, controllability and thermal effectiveness [2].
To operate properly the brake system should have the following requirements:

- The brakes must be strong enough to stop the vehicle with in a minimum distance in an emergency.

- The driver must have proper control over the vehicle during braking and vehicle must not skid.

- The brakes must have well anti fade characteristics widely used than any other brake design. i.e. their effectiveness should not decrease with constant prolonged application.

- The brakes should have well anti wear properties.

The important requirements of the brake drum are following:

- It should provide a surface having well anti wear qualities.

- It should allow the optimum rate of heat transfer. Heat is generated during each brake application and it must be dissipated to the atmosphere immediately, because the next brake application would again produce more heat. Any excess heating of brakes would cause the drum to expand resulting in loss of effective pedal travel and fading of brake lining.

- It should have sufficient strength but minimum weight.

- It should be able to be accommodated within the wheel space available.

The design and analysis of brake requires software that has designing and analyzing tools. CATIA and ANSYS are some of commercially available engineering software which has many design and analyses tools. They enable to build solid models, analyse and simulate the fitness of the model by applying various loads. To design, they usually uses CAD tool, and for analysis they have a solver that have a finite element method tool.

ANSYS software is used to design products and semiconductors, as well as to create simulations that test a product's durability, temperature distribution, fluid movements, and electromagnetic properties [3]. ANSYS, like many other FE-programs, is also divided into three main parts (processors) which are called preprocessor, solution processor, \& postprocessor.

Preprocessor: To do this, FEA software typically uses a CAD representation of the physical model and breaks it down into small pieces called finite "elements". This process is called "meshing." The higher the quality of the 
mesh (collection of elements), the better the mathematical representation of the physical model. The primary purpose of an element is to connect nodes with predictable mathematical equations based on stiffness between nodes; the type of element used often depends upon the problem to be solved. Each element is comprised of 2 or more "nodes" which help define its shape as well as to convey physical reactions from one element to the next. The "finite" in FEA comes from the fact that there are a known number of elements in a finite element model. The solver adds up the individual behaviors of each element to predict the behavior of the entire physical system. Other aspects of the preprocessing phase involve identifying material properties and environmental conditions the design will be subject to. These conditions include various forms of physical forces (loads, pressures, moments, etc.), thermal loads and conditions (temperature, conductivity, convection, etc.), and constraints (fixed, pinned, frictionless/symmetrical, etc.).

Solver: ANSYS Workbench employs 3 of the ANSYS solvers and automatically chooses the most appropriate or efficient solver for the job at hand. In addition to linear/static, ANSYS Workbench performs Coupled analysis types (thermal-stress, stress-modal, thermal-stressmodal) as well as some limited non-linear analysis types (thermal with temperature-dependent material properties and convection, geometric/contact with contact supporting lift-off). All solver settings and iteration propagations from one solve step to the next are performed automatically.

Post-processing: is used to create graphical displays that show the distribution of stresses, strains, deformations, temperatures, and other aspects of the model. Interpretation of these post-processed results is the key to identifying areas of potential concern (weak areas in a model), areas of material waste (areas of the model bearing little or no load), or valuable information on other model performance characteristics (thermal, modal) that otherwise would not be known until a physical model were built and tested \{prototype $\}$ [4].

This study is focused on the design and analysis of truck's brake drum and shoe to observe the effect of engineering materials on the brake performance of heavy duty truck. The model is designed by using CATIA V5 software. ANSYS has been used to analyse the structural and thermal properties of the built model.

\subsection{Background of the study}

Brake is a control mechanism mounted on vehicle to control the speed of the vehicle by applying brake pressure at the road wheel. Depending on the type of operation brake can be classified into hydraulic, pneumatic, hydro-pneumatic, and electric. In the case of pneumatic brake, commonly used on trucks, the pedal force applied by the driver on the brake pedal opens the brake valve to allow compressed air to pass into the brake chamber and turns the cam shaft to actuate the brake shoe /pad against the rotating drum. Due to the applied brake pressure, the kinetic energy of the vehicle is converted into heat energy at the road wheel. The energy absorbed by a brake depends upon the type of motion of the moving body. The motion of a body may be either puretranslation or pure- rotation or a combination of both translation and rotation.

The energy corresponding to these motions is said to be kinetic energy. The energy absorbed by the brake and transformed into heat must be dissipated to the surrounding air in order to avoid excessive temperature rise of the brake lining. The temperature rise depends upon the mass of the brake drum, the braking time and the heat dissipation capacity of the brake. The highest permissible temperatures recommended for different brake lining materials are given as, for leather, fiber and wood facing from 65 to $70^{\circ} \mathrm{C}$, for asbestos and metal surfaces that are slightly lubricated from 90 to $105^{\circ} \mathrm{C}$, for automobile brakes with asbestos block lining from 180 to $225^{\circ} \mathrm{C}$ [5].

Since the energy absorbed (or heat generated) and the rate of wear of the brake lining at a particular speed are dependent on the normal pressure between the braking surfaces, therefore it is an important factor in the design of brakes. The permissible normal pressure between the braking surfaces depends upon the material of the brake lining, the coefficient of friction and the maximum rate at which the energy is to be absorbed.

The material used for the brake lining should have high coefficient of friction with minimum fading (In other words, the coefficient of friction should remain constant over the entire surface with change in temperature), low wear rate, high heat resistance, high heat dissipation capacity, low coefficient of thermal expansion, adequate mechanical strength, and it should not be affected by moisture and oil [5].

Scientists and scholars are working hard to find the best design to dissipate heat energy rapidly in order to increase the brake performance. Nowadays; there are many literatures which were discussed on the vehicle brake drum design and analysis to improve the performance of brake. Some of these research findings are presented as bellow.

In their study to approve the functionality after modification made on the actual brake drum, Anup Kumar and R. Sabarish (2014), tested the strength and heat removal ability of brake drum. From the transient temperature test they observed that the temperature is increasing with each cycle. This showed them that the cooling time provided is not sufficient to cool the drum.

To get more accurate temperature distributions they determined convection co-efficient (h) value by analytical or experimental prediction and incorporated into model .They checked the design by comparing the maximum obtained stress, obtained in analysis against the standard allowable stress value. They found that the design was safe and the brake drum functioned properly under the given load conditions [6]. 
Durgesh Kaiwart \& Yogesh Kumar Tembhurne 2017, studied on the comparison of structural and thermal analysis of disc brake using various materials, they discovered al-nico alloy \& titanium alloy are a good material for brake disc from compare to cast iron \& structural steel [7].

DVSRBM SUBRAMANYAM \& L.SRAVANI concluded that beside general material, aluminum metal matrix (ks1275) can also be use as the material for drum brake because which is economically less cost and less weight ratio gives nearly same stress and deformation value in static analysis and giving good thermal distribution value [8].

The determination of brake temperature is important for the analysis and design brake of a brake system. Excessive temperatures will cause a decrease in brake torque production - commonly called brake fade - and may cause increased brake lining wear, brake system failure, and damage to ad-jacent components such as bearings and tires [2].

\subsection{Objective of the study}

The objectives of this study were:

1. To design heavy duty brake drum using CATIA V5

2. To design heavy duty brake shoe using CATIA V5

3. To analyze the structural and thermal characteristics of brake drum using ANSYS 14.

4. To analyze the structural and thermal characteristics of brake shoe using ANSYS 14.

5. To discuss on the result of the design by using various brake materials.

\subsection{The purpose of the study}

On this research it is aimed to find an alternative brake material for heavy duty vehicle brake drum and brake shoe by using four brake materials as a design variables and comparing their structural and thermal characteristics using the same model and analysis software.

\subsection{Significant of the study:}

The finding of the study would have positive impact on the development of engineering knowledge and skill.

$\circ$ It is helpful to develop the design capability using CAD software (CATIA)

O It is helpful to develop the analysis capability using analysis software (ANSYS)

o From industrial perspective the findings may bring alternative materials for consideration as brake materials.

\subsection{Research problems:}

The drop in brake performance to control motor vehicle during down hill drive that normally needs continuous application of brake to control the speed of the truck is a challenge for truck drivers. The consequence of failure of brake is dangerous because it has great possibility to bring the car into crash and damage. As the result of crash, the loss of materials and sometimes loss of life could be happen. There are various factors that contribute to the failure of brake to control the truck; some of them are brake design, technical problem, high vehicle speed, road type, and weather condition [1].
Theoretically, the heat generated during braking is designed to be absorbed by the drum in the process of conduction and the surrounding air in the process of convection, some amount of heat is dissipated by radiation from the brake system. Poor design and low quality of materials of the truck drum brake are insufficient to handle continuous brake application because of rapid wear and low thermal dissipation which then increases the drum temperature and causes early fade of brake.

This research study is focused on the existing truck drum brake design \& materials, heat dissipation capacity and finding the solutions for improving heat dissipation of brake by using different brake materials. To construct the brake drum and shoe Catia has been used and to analyse the brake drum Ansys software is used.

\section{Brake drum design}

The design or capacity of a brake depends upon the following factors: [5]

- The unit pressure between the braking surfaces,

- The coefficient of friction between the braking surfaces,

- The peripheral velocity of the brake drum,

- The projected area of the friction surfaces, and

- The ability of the brake to dissipate heat equivalent to the energy being absorbed.

The brake drum geometry of this study is identified and its parameters are shown under Table 1 [9].

Table 1. Parameters of Brake drum design

\begin{tabular}{|l|l|}
\hline Category & $\begin{array}{l}\text { Commercial heavy } \\
\text { duty light truck }\end{array}$ \\
\hline $\begin{array}{l}\mathrm{W}_{\mathrm{L}} \text { (Loaded Weight) } \\
\mathrm{Kg}^{-}\end{array}$ & 30,000 \\
\hline $\begin{array}{l}\mathrm{W}_{\mathrm{c}}(\text { Curb Weight) } \\
\mathrm{Kg}\end{array}$ & 12,290 \\
\hline $\mathrm{V}_{\max }(\mathrm{Km} / \mathrm{h})$ & 75 \\
\hline $\begin{array}{l}\text { Brake surface } \\
\text { diameter(mm) }\end{array}$ & 420 \\
\hline Overall depth (mm) & 241.3 \\
\hline $\begin{array}{l}\text { Brake surface flat } \\
\text { (mm) }\end{array}$ & 187.45 \\
\hline $\begin{array}{l}\text { Bolt circle diameter } \\
\text { (mm) }\end{array}$ & 285.75 \\
\hline Pilot diameter (mm) & 239.776 \\
\hline $\begin{array}{l}\text { Back plate thickness } \\
\text { (mm) }\end{array}$ & 14.22 \\
\hline Bolt holes (mm) & $10 / 20.574$ \\
\hline
\end{tabular}

\subsection{Brake Materials}

The four materials chosen for the analyses are Carbon Steel, Al alloy, Al Metal Matrix

Composite (MMC) and Cast iron. Carbon steel and cast iron are commonly used brake materials. Their property is shown under Table 2 [2], [5], [6], [7], [10], [11], \& [12]. 


\begin{tabular}{|l|l|l|l|l|}
\multicolumn{5}{c|}{ Table 2. Brake materials and properties } \\
\cline { 2 - 5 } & $\begin{array}{l}\text { Cast } \\
\text { iron }\end{array}$ & $\begin{array}{l}\text { Carbon } \\
\text { steel }\end{array}$ & $\begin{array}{l}\text { Al alloy } \\
(\text { ADC12) }\end{array}$ & $\begin{array}{l}\text { Al -MMC } \\
\text { (FD205- } \\
\text { T5) }\end{array}$ \\
\hline $\begin{array}{l}\text { Density } \\
\left(\mathrm{Kg} / \mathrm{m}^{3}\right)\end{array}$ & 7113.73 & 7850 & 2770 & 2820.18 \\
\hline $\begin{array}{l}\text { Young's } \\
\text { modules(Mpa) }\end{array}$ & 100000 & 210000 & 7100 & 98000 \\
\hline Poisons ratio & 0.3 & 0.3 & 0.33 & 0.33 \\
\hline $\begin{array}{l}\text { Thermal } \\
\text { conductivity } \\
\left.\text { (W/mm }{ }^{\circ} \mathrm{C}\right)\end{array}$ & 0.04721 & 0.036 & 0.154 & 0.1478 \\
\hline $\begin{array}{l}\text { Specific heat } \\
(\mathrm{J} / \mathrm{Kg} \mathrm{K})\end{array}$ & 401.664 & 420 & 921 & 828.432 \\
\hline
\end{tabular}

\subsection{Design of drum brake}

The design of the drum is done using the parameters of brake drum in CATIA, the views are extracted and dimensions were generated for front \& top views and the views of drum are shown under figure 1.
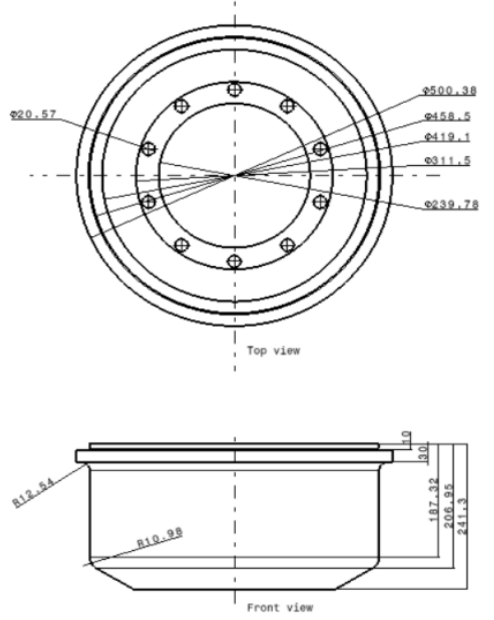

Fig. 1. Brake Drum Design

\subsection{Brake shoe Design}

The design of the brake shoe has been done in CATIA using the parameters of brake shoe, the front; top and isometric views were projected from the designed brake shoe as shown under figure 2.
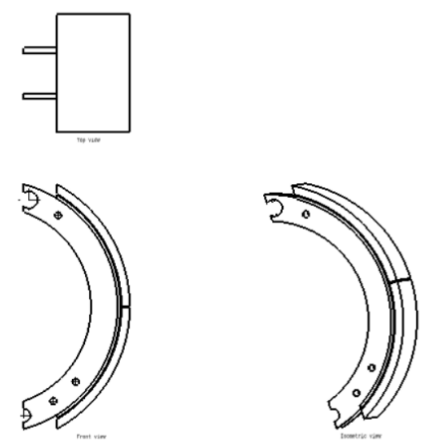

Fig. 2 Brake Shoe Design
3. Analysis Using Ansys 14.5- Work Bench Introduction: Simple shapes and simple problems can be, and often are done by hand. Most real world parts and assemblies are far too complex to do accurately, let alone quickly, without use of a computer and appropriate analysis software. Finite Element Method (FEM) has been used as a tool to solve engineering problems commercially in industrial applications. Commercial software have FEA tool, like ANSYS, ABAQUS, FLUENT, and Comsol Multiphysics etc.

Finite Element Analysis (FEA) is a mathematical representation of a physical system comprising a part/assembly (model), material properties, and applicable boundary conditions (collectively referred to as preprocessing), the solution of that mathematical representation (solving), and the study of results of that solution \{postprocessing $\}[4]$.

\subsection{Structural Analysis of Brake Drum}

\section{(a) Import model:}

In the pre-processing stage of FEM the brake drum and shoe geometry were imported from CATIA v-5 into ANSYS14.5 -workbench as shown under figure $3 \& 4$ respectively.

\section{(b) Load and fixed support:}

To study the structural load characteristics of brake materials, applied load and support were determined .Brake pressure of $1.5 \mathrm{MPa}$ is applied on the face of brake drum and on the brake lining as shown under Fig. $5 \& 6$ respectively. Fig $7 \& 8$ illustrate fixed support.

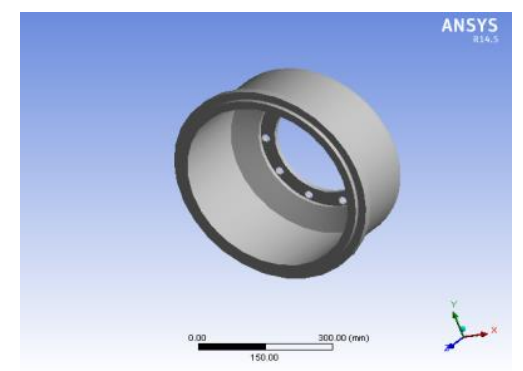

Fig. 3 brake drum

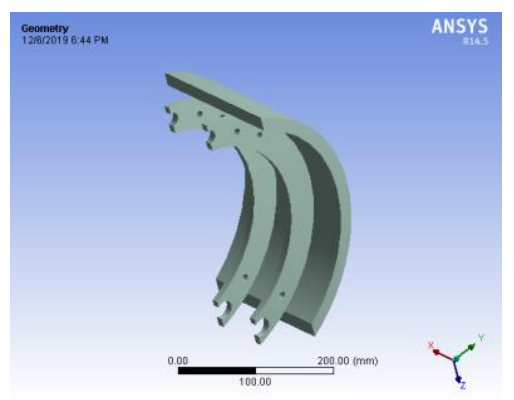

Fig. 4 brake shoe 


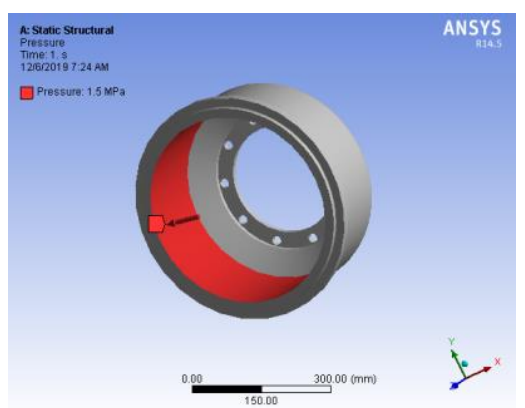

Fig. 5 1.5MPa load on drum

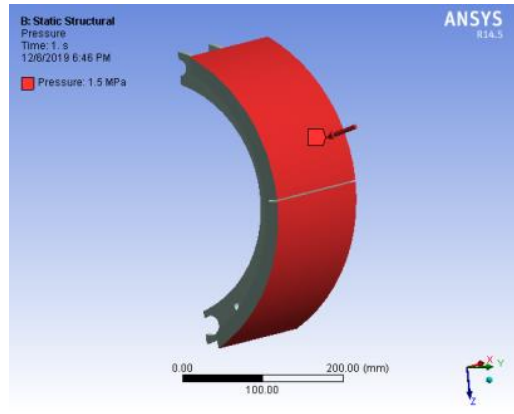

Fig. 6 1.5MPa load on shoe

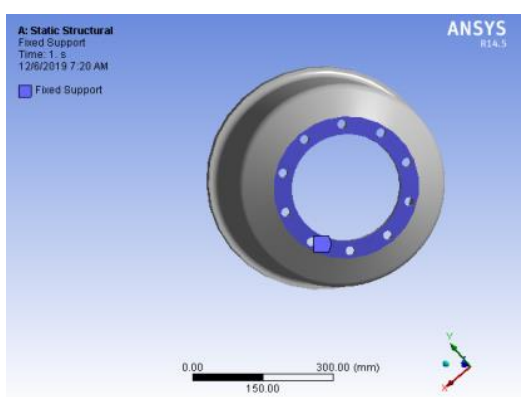

Fig. 7 Fixed support of brake drı

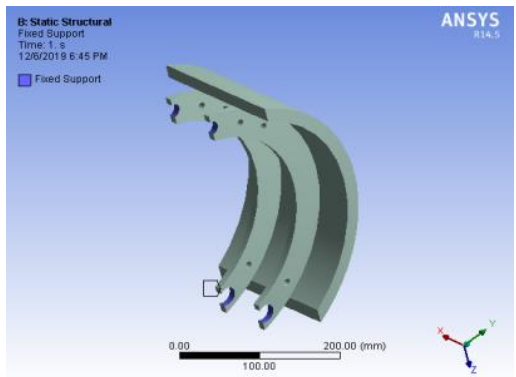

Fig. 8 Fixed support of brake shoe

\section{(c) Meshing:}

The process of representing a physical domain with finite elements is referred to as meshing, and the resulting set of elements is known as the finite element mesh. Meshing of the brake drum is shown under Fig 9.

Mesh Type: Tetrahedral

No. of nodes: 41273

No. of elements: 23051

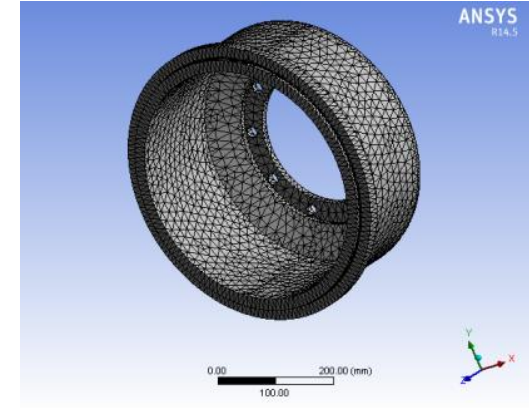

Fig.9 Meshing of a brake drum

\section{Structural analysis of carbon steel brake drum}

Carbon steel drum brake has showed maximum total deformation, max. equivalent (von-Mises) stress, \& max. equivalent elastic strain at the face of the drum highlighted by red color, each have magnitude of $0.020502 \mathrm{~mm}, 18.783$ $\mathrm{MPa}$, \& 8.9446e-5 mm/mm respectively. The drum's bolt holes area has lower deformation, stress \& strain as indicated by blue color. The detail is shown under Fig. 10, $11 \& 12$.

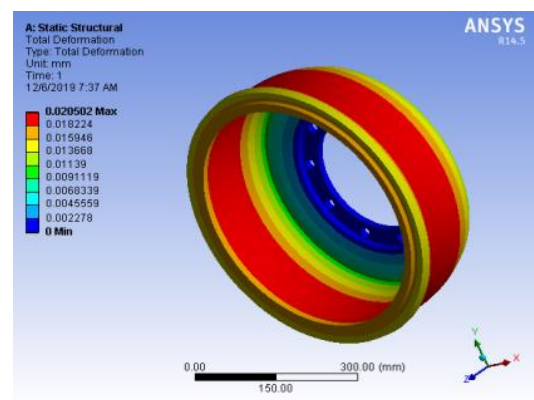

Fig.10 Total deformation

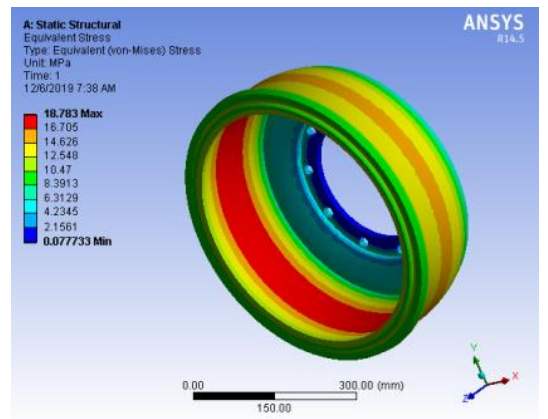

Fig.11 Stress

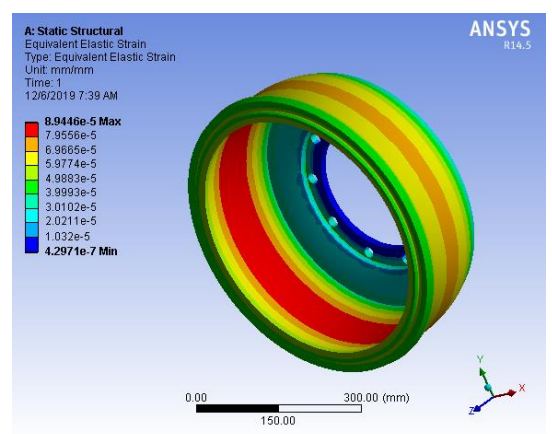

Fig.12 Strain 


\section{Structural analysis of Al Alloy brake drum}

Al Alloy brake drum has showed maximum total deformation, Max. equivalent (von-Mises) stress, \& Max. equivalent elastic strain at the face of the drum as indicated by red color and minimum deformation, Min. equivalent (von-Mises) stress, \& Min. equivalent elastic strain at the bolt holes area of the drum as indicated by blue color. Fig. $13,14 \& 15$ show the detail of deformation, stress \& strain of Al Alloy brake drum.

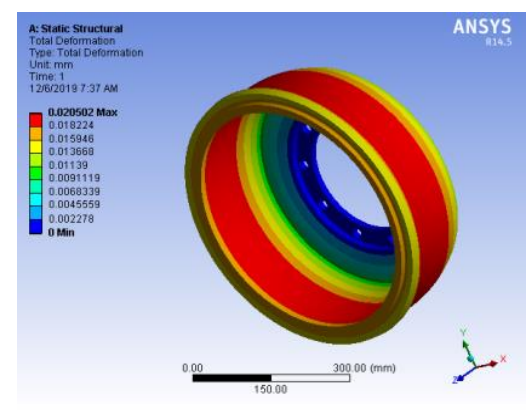

Fig. 14 Total deformation

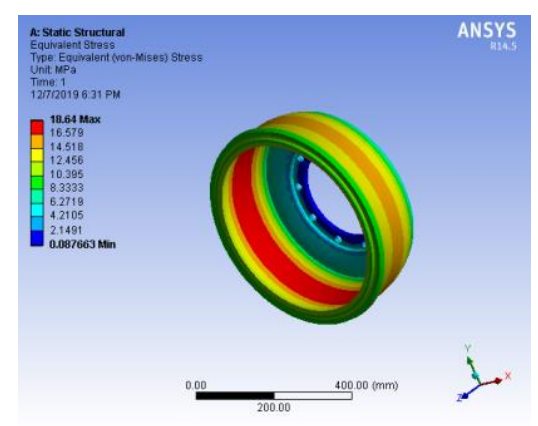

Fig. 15 Stress

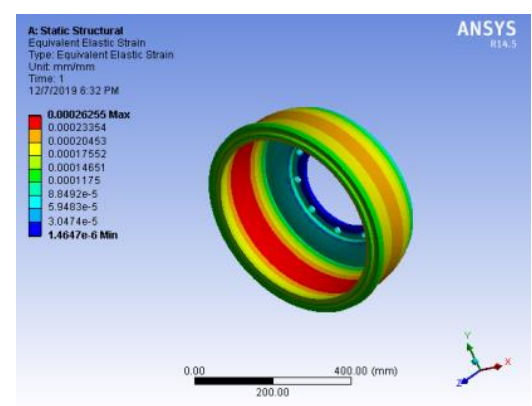

Fig. 16 Strain

\section{Structural analysis of Al Metal Matrices Composite brake drum}

Al Metal Matrices Composite brake drum has showed maximum total deformation of $0.044231 \mathrm{~mm}$, maximum and minimum equivalent (von-Mises) stress of $18.64 \&$ $0.087663 \mathrm{MPa}$ respectively and maximum minimum equivalent elastic strain of $0.00019021 \mathrm{~mm} / \mathrm{mm}$ and $1.0611 \mathrm{e}-$ $6 \mathrm{~mm} / \mathrm{mm}$ respectively. Fig. 17, $18 \& 19$ show the deformation, stress \& strain of Al Metal Matrices Composite brake drum.

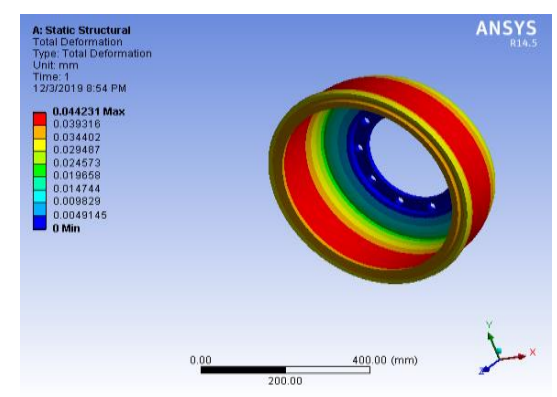

Fig. 17 Total deformation

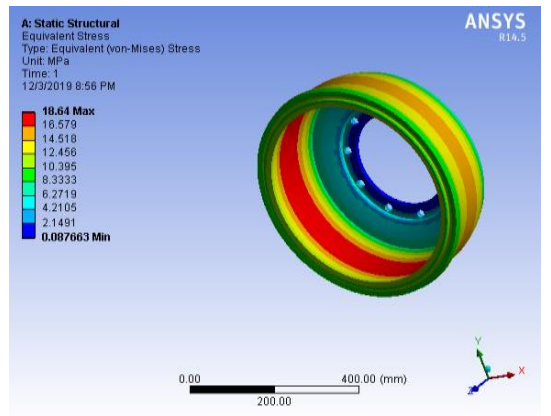

Fig. 18 Stress

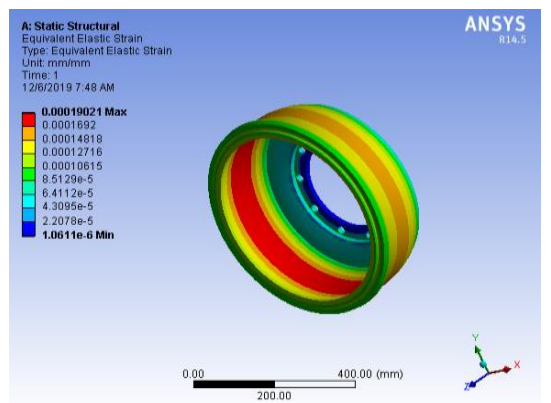

Fig. 19 Strain

\section{Structural analysis of Cast iron brake drum}

Cast iron brake drum has showed maximum total deformation of $0.043054 \mathrm{~mm}$, maximum and minimum equivalent (von-Mises) stress of $18.783 \& 0.077733 \mathrm{MPa}$ respectively and maximum minimum equivalent elastic strain of $0.00018784 \mathrm{~mm} / \mathrm{mm}$ and $9.0238 \mathrm{e}-7 \mathrm{~mm} / \mathrm{mm}$ respectively. Fig. 20, 21\&22 show the deformation, stress \& strain of Cast iron brake drum. 

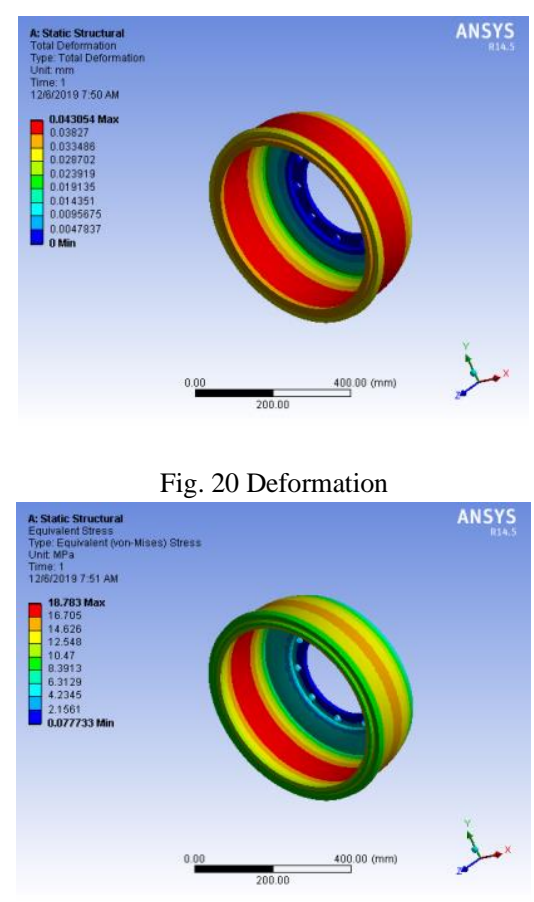

Fig. 21 Stress

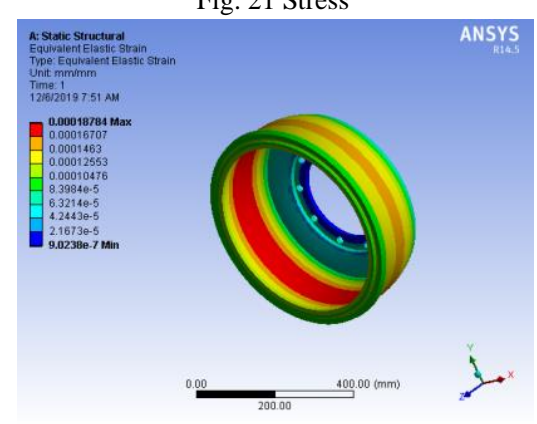

Fig. 22 Strain

\subsection{Structural analysis of brake shoe}

\section{Meshing:}

The element size and type of mesh were defined and the brake shoe has been meshed as shown in Fig. 23. The statistics of nodes and elements are:

Mesh Type: Tetrahedral

No. of nodes: 16738

No. of elements: 8916

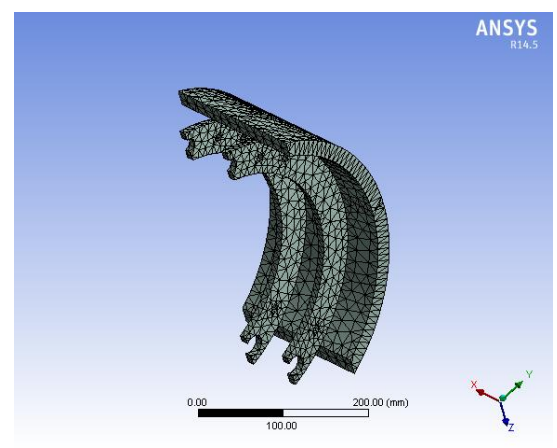

\section{Structural analysis of carbon steel brake Shoe}

Carbon steel brake shoe has showed maximum total deformation, equivalent (von-Mises) stress, \& equivalent elastic strain of $0.058955 \mathrm{~mm}, 238.3 \mathrm{MPa}, \& 0.0011348$ $\mathrm{mm} / \mathrm{mm}$ respectively as highlighted by red color and minimum deformation, equivalent (von-Mises) stress, \& Min. equivalent elastic strain of $0.27163 \mathrm{MPa} \& 2.5266 \mathrm{e}-6$ $\mathrm{mm} / \mathrm{mm}$ respectively as indicated by blue color. Fig. 24, $25 \& 26$ shows the deformation, stress \& strain of carbon steel brake shoe.

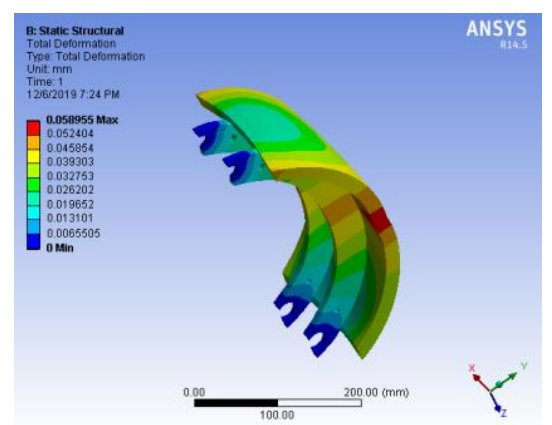

Fig. 24 Total deformation

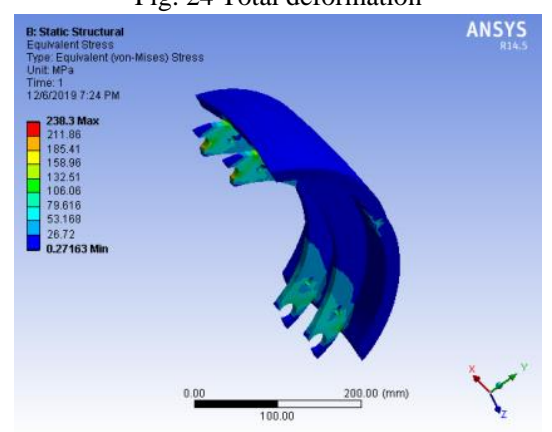

Fig. 25 Stress

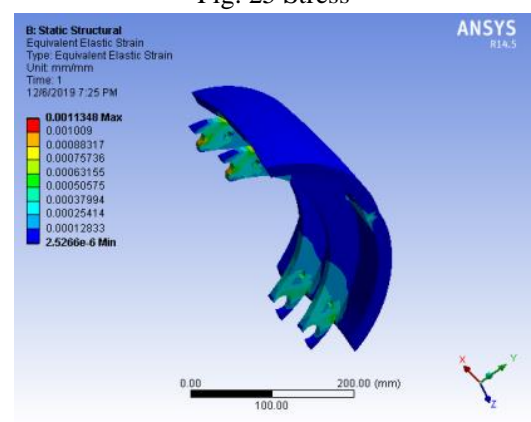

Fig. 26 Strain

\section{Structural analysis of Al Alloy brake Shoe}

Al Alloy brake shoe has showed maximum total deformation of $0.17312 \mathrm{~mm}$, maximum and minimum equivalent (von-Mises) stress of $229.68 \& 0.28859 \mathrm{MPa}$ respectively and maximum minimum equivalent elastic strain of $0.003235 \mathrm{~mm} / \mathrm{mm}$ and $7.2523 \mathrm{e}-6 \mathrm{~mm} / \mathrm{mm}$ respectively. Fig. 27, 28\&29 show the deformation, stress \& strain of Al Alloy brake shoe.

Fig. 23 meshing of brake shoe 


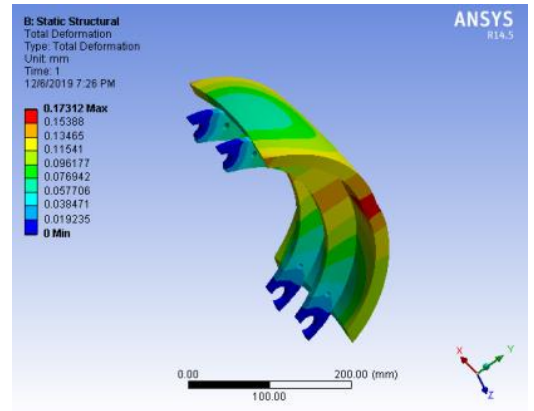

Fig. 27 Total deformation

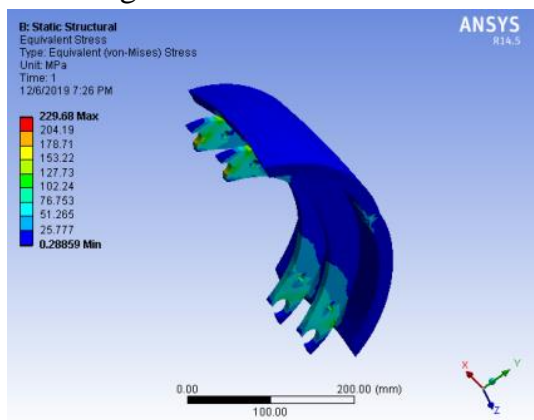

Fig. 28 Stress

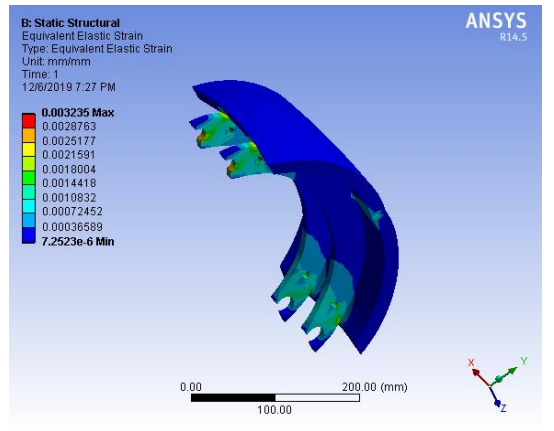

Fig. 29 Strain

\section{Structural analysis of Al MMC brake Shoe}

Al MMC brake shoe has showed maximum total deformation of $0.12542 \mathrm{~mm}$, maximum and minimum equivalent (von-Mises) stress of $229.68 \& 0.28859 \mathrm{MPa}$ respectively and maximum minimum equivalent elastic strain of $0.0023437 \mathrm{~mm} / \mathrm{mm}$ and $5.2542 \mathrm{e}-6 \mathrm{~mm} / \mathrm{mm}$ respectively. Fig. 30, 31\&32 show the deformation, stress \& strain of Al MMC

brake shoe.

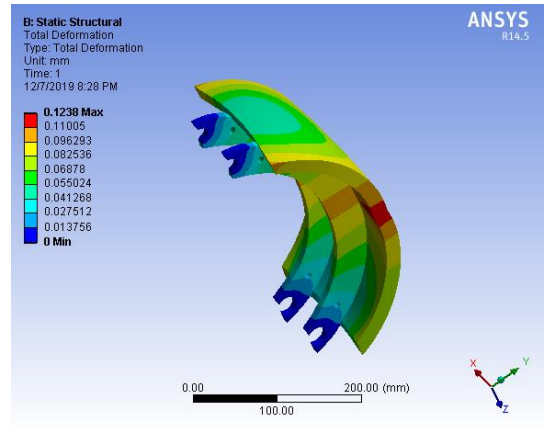

Fig. 30 deformation

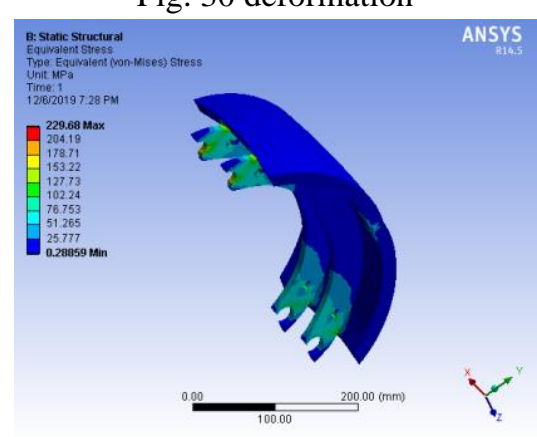

Fig. 31 Stress

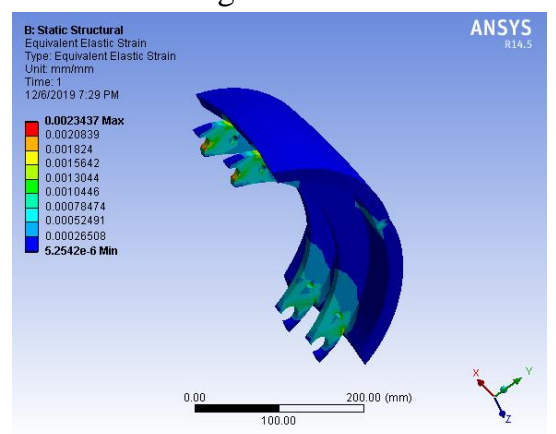

Fig. 32 Strain

\section{Structural analysis of Cast iron brake Shoe}

Cast iron brake shoe has showed maximum total deformation of $0.1238 \mathrm{~mm}$, maximum and minimum equivalent (von-Mises) stress of $238.3 \quad \& \quad 0.27163 \mathrm{MPa}$ respectively and maximum minimum equivalent elastic strain of $0.002383 \mathrm{~mm} / \mathrm{mm}$ and $5.3058 \mathrm{e}-6 \mathrm{~mm} / \mathrm{mm}$ respectively. Fig. 33, 34\&35 show the deformation, stress \& strain of Cast iron brake shoe. 


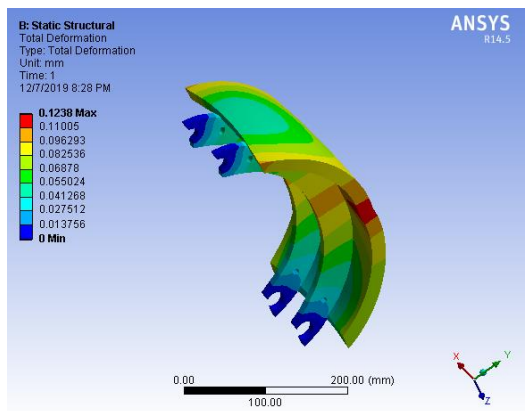

Fig. 33 Deformation

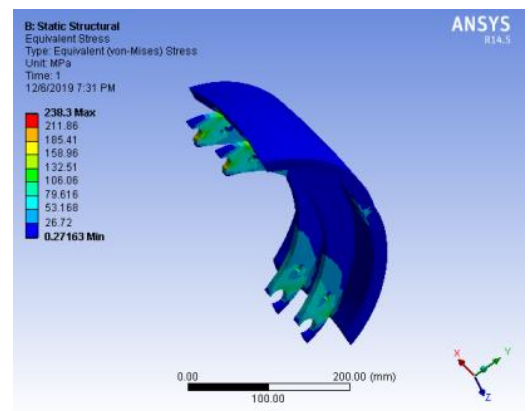

Fig. 34 Stress

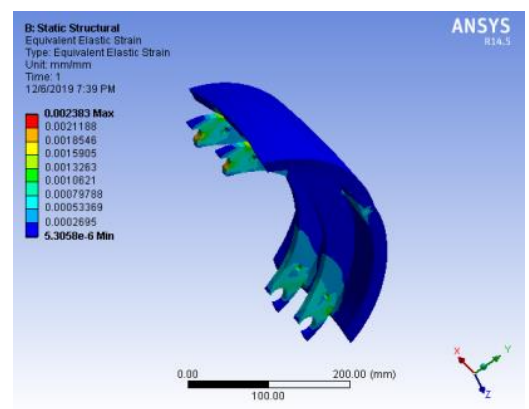

Fig. 35 Strain

\subsection{Thermal Analysis brake drum \& Shoe}

The temperature applied to study the steady state thermal analysis of the brake materials is $90{ }^{\circ} \mathrm{C}$, and the convection coefficient is $5 \mathrm{e}-006 \mathrm{~W} / \mathrm{mm}^{2}$. Fig. 36-Fig.39 illustrates the thermal study.

\section{Thermal analysis of brake drum}

Aluminum alloy brake drum has showed maximum and minimum temperature of $90 \quad{ }^{\circ} \mathrm{C} \quad \& \quad 88.519 \quad{ }^{\circ} \mathrm{C}$ respectively .The maximum\& minimum total heat flux of $0.0071645 \mathrm{~W} / \mathrm{mm}^{2}$ and $6.1651 \mathrm{e}-6 \mathrm{~W} / \mathrm{mm}^{2}$ respectively. Fig. $40 \& 41$ show the temperature $\&$ heat flux of Aluminum alloy brake drum.

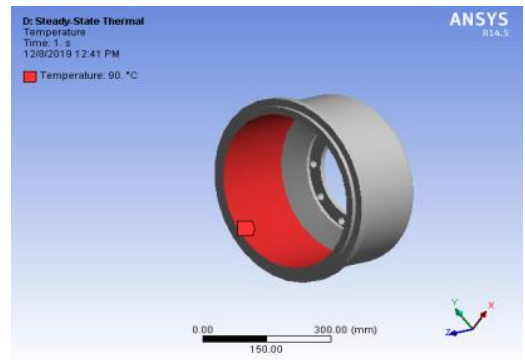

Fig. 36 Temperature $90^{\circ} \mathrm{C}$

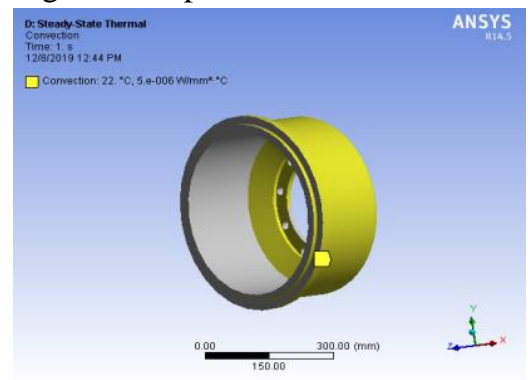

Fig. 37 Convection 5e-006W/mm ${ }^{2}$

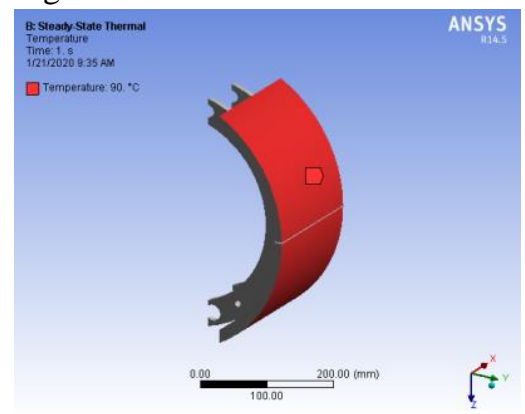

Fig. 38 Temperature $90{ }^{\circ} \mathrm{C}$

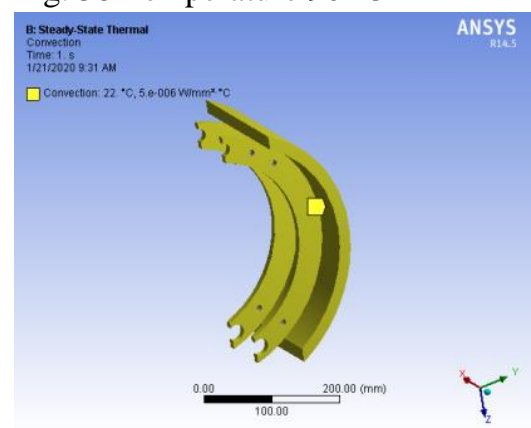

Fig. 39 Convection 5e-006W/mm²

\section{Thermal analysis of Aluminum Metal Matrices brake drum}

Aluminum MMC brake drum has showed maximum and minimum temperature of $90 \quad{ }^{\circ} \mathrm{C} \quad \& \quad 88.458 \quad{ }^{\circ} \mathrm{C}$ respectively. The maximum\& minimum total heat flux of $0.0071609 \mathrm{~W} / \mathrm{mm}^{2}$ and $6.1593 \mathrm{e}-6 \mathrm{~W} / \mathrm{mm}^{2}$ respectively. Fig $42 \& 43$ show the temperature \& heat flux of Aluminum MMC brake drum. 


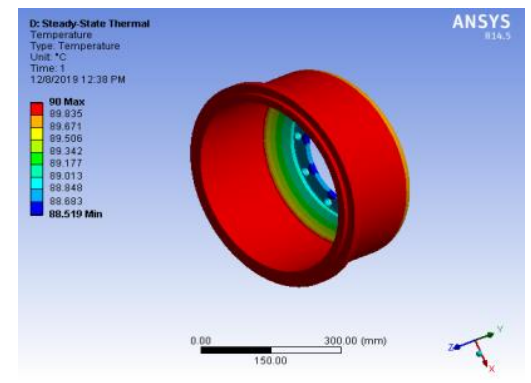

Fig. 40 Temperature

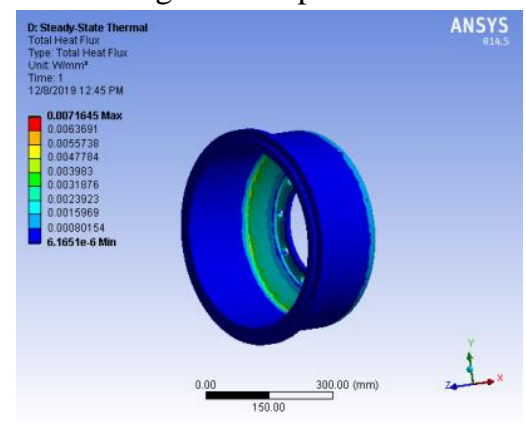

Fig. 41 Heat Flux

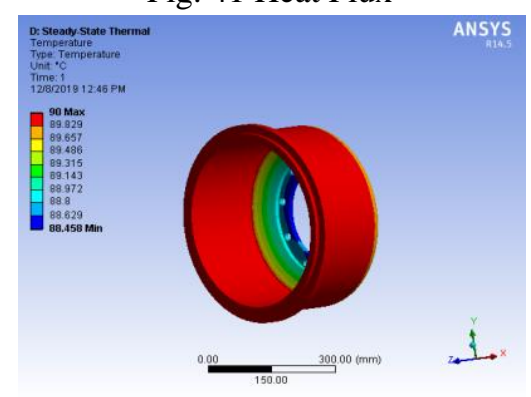

Fig. 42 Temperature

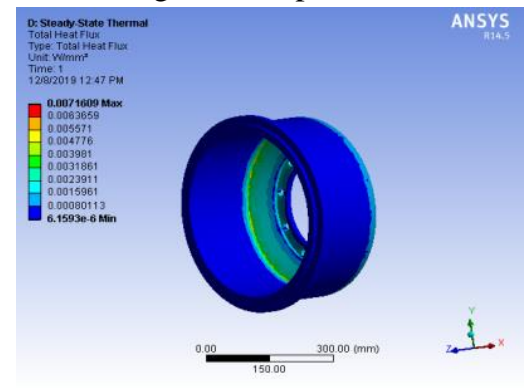

Fig. 43 Heat flux

Carbon Steel brake drum has showed maximum and minimum temperature of $90 \quad{ }^{\circ} \mathrm{C} \quad \& \quad 85.591 \quad{ }^{\circ} \mathrm{C}$ respectively .The maximum\& minimum total heat flux of $0.0069924 \mathrm{~W} / \mathrm{mm}^{2}$ and $5.8853 \mathrm{e}-6 \mathrm{~W} / \mathrm{mm}^{2}$ respectively. Whereas, Cast Iron brake drum has showed maximum and minimum temperature of $90 \quad{ }^{\circ} \mathrm{C} \quad \& \quad 85.591 \quad{ }^{\circ} \mathrm{C}$ respectively .The maximum\& minimum total heat flux of $0.0069924 \mathrm{~W} / \mathrm{mm}^{2}$ and $5.8853 \mathrm{e}-6 \mathrm{~W} / \mathrm{mm}^{2}$ respectively. Fig.
44, Fig.45, Fig. $46 \& 47$ show the temperature \& heat flux of Carbon Steel \& Cast Iron brake drum.

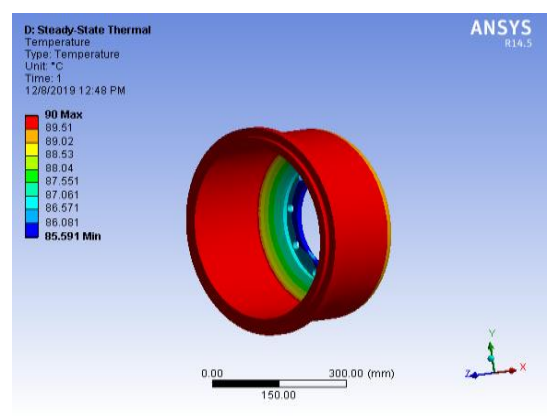

Fig. 44 Temperature

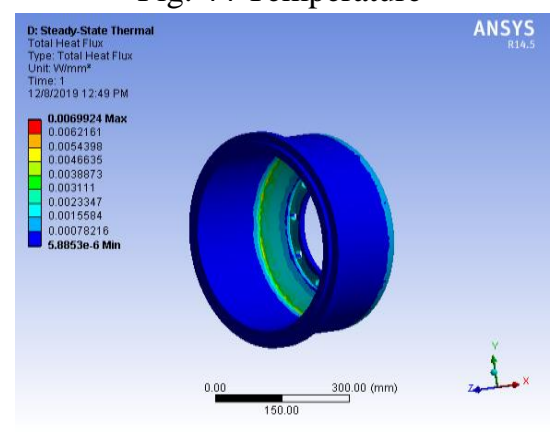

Fig. 45 Heat flux

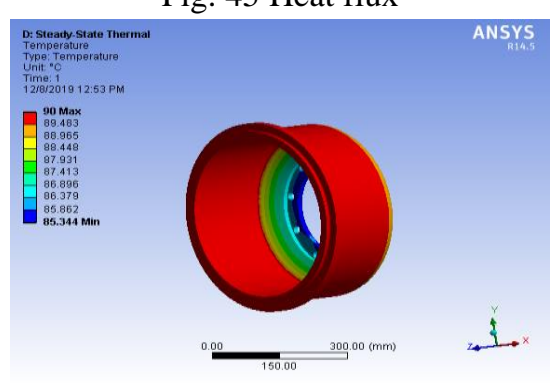

Fig. 46 Temperature

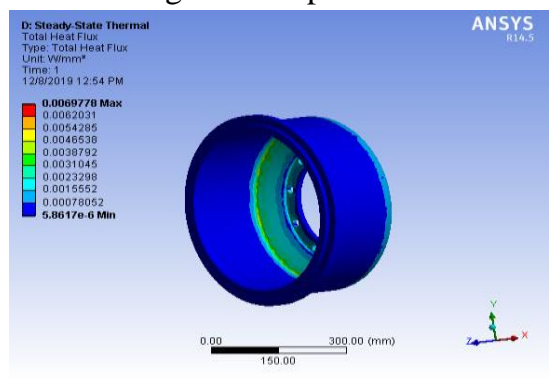

Fig. 47 Heat flux

\section{Thermal analysis of brake Shoe}

Aluminum alloy brake shoe has showed maximum and minimum temperature of $90 \quad{ }^{\circ} \mathrm{C} \quad \& \quad 88.115 \quad{ }^{\circ} \mathrm{C}$ respectively .The maximum\& minimum total heat flux of $0.012893 \mathrm{~W} / \mathrm{mm}^{2}$ and $0.00017892 \mathrm{~W} / \mathrm{mm}^{2}$ respectively. Fig. $48 \& 49$ show the temperature $\&$ heat flux of Aluminum alloy brake shoe. 
Aluminum Metal Matrix Composite brake shoe showed maximum and minimum temperature of $90 \mathrm{oC} \& 88.038 \mathrm{oC}$ respectively .The maximum\& minimum total heat flux of $0.012883 \mathrm{~W} / \mathrm{mm} 2$ and $0.00017891 \mathrm{~W} / \mathrm{mm} 2$ respectively. Fig. 50\& 51 show the temperature $\&$ heat flux of Aluminum alloy brake shoe.

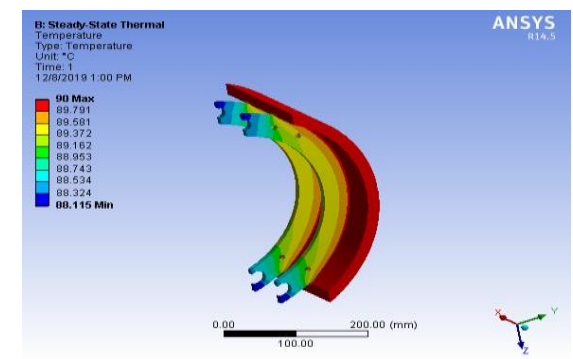

Fig. 48 Temperature

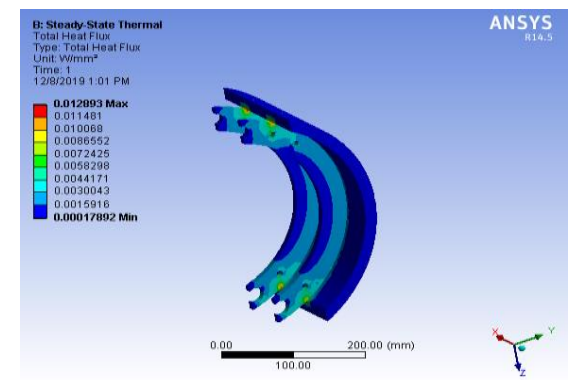

Fig. 49 Heat flux

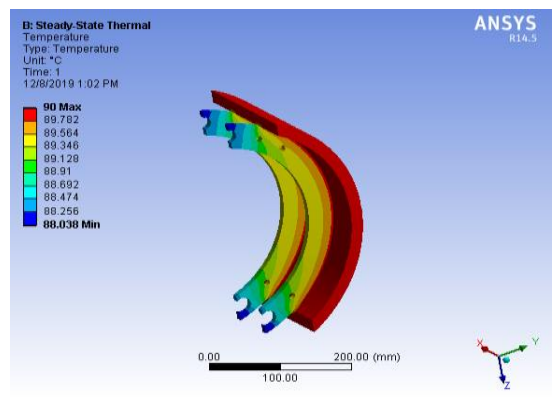

Fig. 50 Temperature

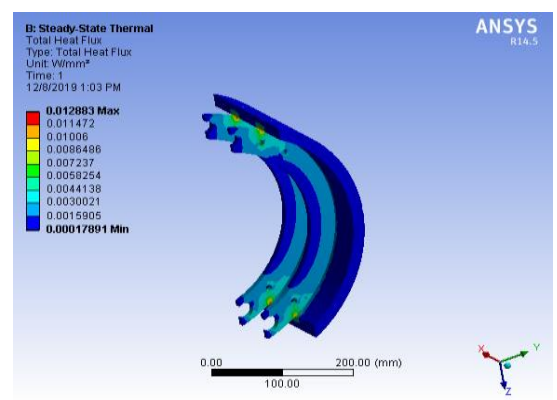

Fig. 51 Heat flux

Carbon Steel brake showed maximum and minimum temperature of $90 \mathrm{oC} \& 82.451$ oC respectively .The maximum\& minimum total heat flux of $0.012165 \mathrm{~W} / \mathrm{mm} 2$ and $0.00017827 \mathrm{~W} / \mathrm{mm} 2$ respectively.
Whereas, Cast Iron brake shoe showed maximum and minimum temperature of $90 \mathrm{oC} \& 84.127 \mathrm{oC}$ respectively. The maximum\& minimum total heat flux of $0.012382 \mathrm{~W} / \mathrm{mm} 2$ and $0.00017841 \mathrm{~W} / \mathrm{mm} 2$ respectively. Fig. 52, Fig. 53, Fig. 54\& 55 show the temperature \& heat flux of Carbon Steel \& Cast Iron brake shoe.

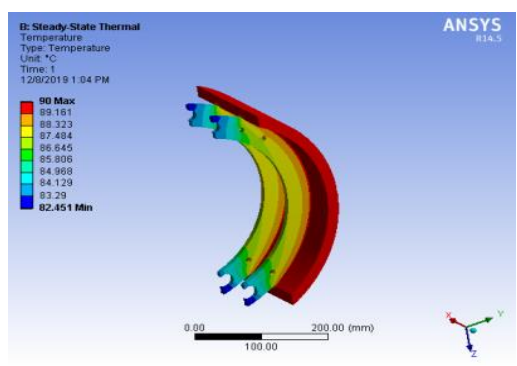

Fig. 52 Temperature

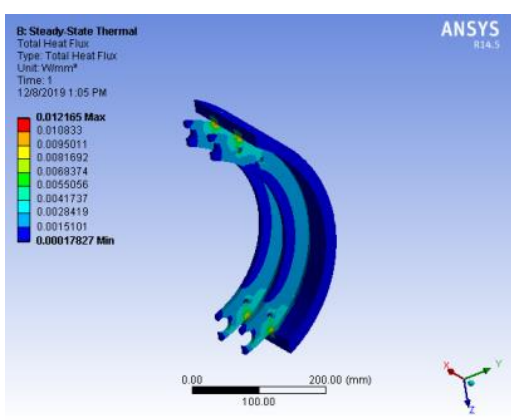

Fig. 53 Heat flux

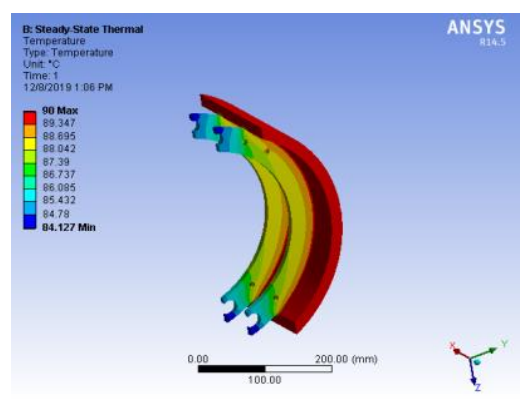

Fig. 54 Temperature

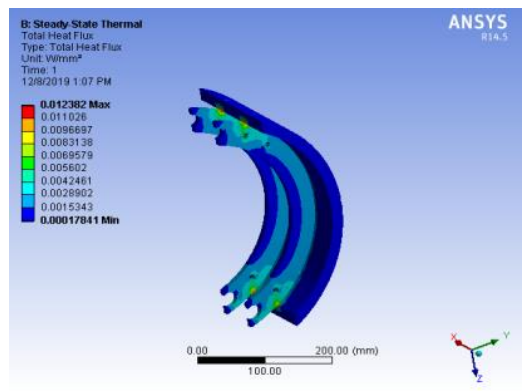

Fig. 55 Heat Flux

\section{FINDINGS}

The structural analysis result of brake drum seen under Fig. 5 to Fig. 22 showed that aluminum alloy have higher deformation than the other three materials for the same applied test pressure of $1.5 \mathrm{MPa}$, whereas Aluminum Metal Matrix Composite (MMC) and cast iron both showed moderate deformation, while, carbon steel has lower deformation than the other three materials. The summary is illustrated under Table 3. 
In the other hand, carbon steel and cast iron had higher stress, while $\mathrm{Al}$ and $\mathrm{Al}$ metal matrix composite had relatively lower stress distribution. The summary is shown under Table 3. Al Alloy has higher strain than the three materials while, carbon steel has lower strain. The summary is shown under Table 3.

Table3.Summary of Structural analysis of Brake drum

\begin{tabular}{|l|l|l|l|}
\hline \multirow{2}{*}{$\begin{array}{c}\text { Brake } \\
\text { Material }\end{array}$} & \multicolumn{3}{|c|}{ Properties } \\
\cline { 2 - 4 } & $\begin{array}{l}\text { Max } \\
\text { Stress } \\
\text { (Mpa) }\end{array}$ & $\begin{array}{l}\text { Max Strain } \\
(\mathrm{mm} / \mathrm{mm})\end{array}$ & $\begin{array}{l}\text { Total } \\
\text { deformation } \\
(\mathrm{mm})\end{array}$ \\
\hline Carbon Steel & 18.783 & $8.94 \mathrm{e}-05$ & 0.020502 \\
\hline Al Alloy & 18.64 & $2.63 \mathrm{e}-04$ & 0.061051 \\
\hline $\begin{array}{l}\text { Al Alloy } \\
\text { MMC }\end{array}$ & 18.64 & $1.90 \mathrm{e}-04$ & 0.044231 \\
\hline Cast Iron & 18.783 & $1.88 \mathrm{e}-04$ & 0.043054 \\
\hline
\end{tabular}

The structural analysis result of the brake shoes seen in Fig. 23 to Fig. 35 depicts that Al alloy had higher deformation than the three materials, whereas, Al metal matrix composite and cast iron have very similar deformation characteristics and carbon steel showed lower deformation property.

In the stress analysis of brake shoe carbon steel and cast iron have slightly higher stress than $\mathrm{Al}$ alloy and $\mathrm{Al}$ metal matrix composite. Al alloy showed higher strain than the three engineering materials whereas Al metal matrix composite and cast iron exhibited similar strain characteristics, while carbon steel have lower strain. The summary of stress, strain and deformation of the brake shoes is shown under Table 4.

\begin{tabular}{|l|l|l|l|}
\multicolumn{2}{c}{ Table4.Summary of Structural analysis of Brake shoes } \\
\hline \multirow{2}{*}{$\begin{array}{c}\text { Brake } \\
\text { Materials }\end{array}$} & $\begin{array}{c}\mid c \\
\text { Max Stress } \\
(\mathrm{Mpa})\end{array}$ & $\begin{array}{l}\text { Max Strain } \\
(\mathrm{mm} / \mathrm{mm})\end{array}$ & $\begin{array}{l}\text { Total } \\
\text { deformation } \\
(\mathrm{mm})\end{array}$ \\
\cline { 2 - 4 } Carbon Steel & 238.3 & $1.13 \mathrm{e}-03$ & 0.058955 \\
\hline Al Alloy & 229.68 & $3.24 \mathrm{e}-03$ & 0.17312 \\
\hline $\begin{array}{l}\text { Al Alloy } \\
\text { MMC }\end{array}$ & 229.68 & $2.34 \mathrm{e}-03$ & 0.12542 \\
\hline Cast Iron & 238.3 & $2.38 \mathrm{e}-03$ & $1.24 \mathrm{e}-01$ \\
\hline
\end{tabular}

The steady state thermal analysis result that has been seen under Fig. 36 to Fig.47 computed for brake drum between four engineering materials by applying $90{ }^{\circ} \mathrm{C}$ and convection coefficient of $5 \mathrm{e}-006 \mathrm{~W} / \mathrm{mm}^{2}$ showed $\mathrm{Al}$ alloy have higher temperature distribution characteristics than cast iron and carbon steel, it has small variation with $\mathrm{Al}$ Metal Matrix Composite. Al alloy \& Al MMC have slightly higher heat flux than carbon steel and cast iron. The summery of temperature and heat flux of the four materials are shown under Table 5.

Similarly, in the steady state thermal analysis result of brake shoe that have been seen under Fig. 48 to Fig. 55, Al Alloy
\& Al MMC showed higher temperature distribution capacity and heat flux while cast iron had higher thermal conductivity and heat flux than carbon steel. The temperature and heat flux of the brake shoe are shown under Table 6.

Table 5. Summary of Thermal analysis of Brake Drum

\begin{tabular}{|l|r|r|}
\hline \multirow{2}{*}{ Brake Materials } & \multicolumn{2}{|c|}{ Properties } \\
\cline { 2 - 4 } & $\begin{array}{l}\text { Max Temperature } \\
\left({ }^{\circ} \mathrm{C}\right)\end{array}$ & Heat Flux $\left(\mathrm{W} / \mathrm{mm}^{2}\right)$ \\
\hline Carbon Steel & 90 & 0.0069924 \\
\hline Al Alloy & 90 & 0.0071645 \\
\hline Al Alloy MMC & 90 & 0.0071609 \\
\hline Cast Iron & 90 & 0.0069778 \\
\hline
\end{tabular}

Table 6. Summary of Thermal analysis of Brake Shoe

\begin{tabular}{|c|c|c|}
\hline \multirow[b]{2}{*}{ Brake Material } & \multicolumn{2}{|c|}{ Properties } \\
\hline & $\begin{array}{l}\text { Max Temperature } \\
\left({ }^{\circ} \mathrm{C}\right)\end{array}$ & Heat Flux $\left(\mathrm{W} / \mathrm{mm}^{2}\right)$ \\
\hline Carbon Steel & 90 & 0.012165 \\
\hline Al Alloy & 90 & 0.012893 \\
\hline Al Alloy MMC & 90 & 0.012883 \\
\hline Cast Iron & 90 & 0.012382 \\
\hline
\end{tabular}

The result obtained on this research supports the works of Dvsrbm Subramanyam \& L.Sravani (2017). In their study on design \& analysis of drum brake using Carbon steel, Al Alloy \& Al MMC as brake materials, they concluded that $\mathrm{Al}$ MMC (Ks1275) can be used as material for drum brake beside general materials. It also supports the study carried out by Durgesh Kaiwart \& Yogesh Kumar Tembhurne (2017), on the comparison of structural and thermal analysis of disc brake using various materials, they discovered al-nico alloy \& titanium alloy are a good material for brake disc from compare to cast iron \& structural steel.

\section{CONCLUSIONS}

By integrating CATIA and ANSYS it is possible to study material effect on the design and analysis of brake performance of heavy duty truck. Engineering materials have significant effect on the design of a product. Aluminum metal matrix composite (Al MMC F3D205-T5) has better characteristics of thermal dissipation capacity and light weight than cast iron and carbon steel (commonly used brake materials) and it have moderate deformation characteristics similar to cast iron. The brake drum and shoe design requirements regarding heat dissipation and weight has been met. Because of its better characteristics, Aluminum metal matrix composite (Al MMC F3D205-T5) can be used as an alternative brake material to build brake drums and shoe.

\section{ACKNOWLEDGMENT}

The researcher would like to appreciate research advisor professor Zhang Lei for her unreserved support and valuable comments and suggestions on this study. 


\section{REFERENCE}

[1] Konrad Reif, 2014, Brakes, Brake Control and Driver Assistance Systems Function, Regulation and Components, Springer

[2] Engineering Design Hand book: Analysis and Design of Automotive Brake Systems, 1976, U.S. Department Of Commerce

[3] Wikipedia, Ansys, en.wikipedia.org

[4] Fundamental FEA Concepts and Applications, A Guidebook for the Use and Applicability of Workbench Simulation Tools from ANSYS, Inc.

[5] R.S. KHURMI \& J.K. GUPTA, 2005 A Text Book of Machine Design, Eurasia Publishing House (PVT.) LTD

[6] Anup Kumar And R. Sabarish,2014, Structural And Thermal Analysis Of Brake Drum, Middle-East Journal Of Scientific Research

[7] Durgesh Kaiwart \&Yogesh Kumar Tembhurne,2017, Comparision Of Structural And Thermal Analysis Of Disc Brake Using Various Materials, International Journal Of Thermal Engineering (Ijte)
[8] Dvsrbm Subramanyam \& L.Sravani, 2017, Design And Analysis Of Drum Brakes, International Journal Of Eminent Engineering Technologies

[9] WEBB, 2011product catalogue, SD-090/DH0411 National Technical Information ServiceRegulation (ASR), Version 002/02.11

[10] Mohammed Abdul Aleem et.al, 2018, Design and Analysis of Drum Brakes, International Journal Of Advanced Technology and Innovative Research

[11] Senthil Kumar et.al ,2017,Structural And Thermal Study Of Aluminum Hybrid Composite Alloy Reinforced With Silicon Carbide And Rice Husk Ash For Automobile Brake Drum, ANNALS Of Faculty Engineering Hunedoara - International Journal Of Engineering.

[12] WABCO, 2011, Anti-Lock Braking System (ABS) and Anti-Slip 